\title{
MUCH BEYOND THE MINIMUM why do brazilian municipalities overallocate their own revenues to healthcare?
}

\author{
José Angelo Machado (1)
}

E-mail: joseangelo@fafich.ufmg.br

\section{Guilherme Quaresma (2)}

E-mail: gquaresma@cedeplar.ufmg.br

\section{Carmem E. Leitão Araújo ${ }_{(\rightarrow)}($ D}

E-mail: carmemleitao@ufc.br

(1) Departamento de Ciência Política, Faculdade de Filosofia e Ciências Humanas da Universidade Federal de Minas Gerais (UFMG) - Belo Horizonte, MG, Brasil.

(2) Departamento de Economia do Centro de Desenvolvimento e Planejamento Regional, Faculdade de Ciências Econômicas da Universidade Federal de Minas Gerais (Cedeplar/FACE/UFMG) - Belo Horizonte, MG, Brasil. .

(3) Departamento de Saúde Comunitária, Faculdade de Medicina da Universidade Federal do Ceará-UFC - Fortaleza, CE, Brasil.

DOI: $10.1590 / 3610700 / 2021$

\section{Introduction}

This work seeks to identify the reasons for Brazilian municipalities overallocating their own revenues to healthcare. Under the original intention of ensuring stable sources of resources for the healthcare sector in a context of financial crisis (Lazzari, 2003; Piola et al., 2016), the earmarking of a minimum of expenditures to be allocated by different levels of federal government to the sector would have an important role in order to commit them to implementing this public policy and ensuring stable sources of revenue for the health sector (Vieira \& Benevides, 2016). The behavior of the Federal Government and the States has been different since the promulgation of Constitutional Amendment $29 / 2000$, considering what has been manifested by the municipalities: while the first two levels of government

Artigo recebido em: 29/06/2020

Aprovado em: 30/12/2020 took some time to adjust to the required minimums, local governments gradually increased the amounts allocated to healthcare in order to quickly exceed the $15 \%$ margin of their own revenues defined as the mandatory constitutional minimum. Although Brazilian municipalities of different population sizes vary substantially in terms of the proportion of their own revenues for healthcare, as it will be discussed below, they have been allocating a proportion clearly higher than the constitutional minimum, reaching an average of $22.9 \%$ in 2018.

In order to identify the reasons which could explain the high allocation degree of expenses incurred using the municipalities' own health revenues, herein considered as a dependent variable, hypotheses regarding the population scale effects of the municipalities were tested; as well as the level of economic and social development of the region in which they operate; the incorporation degree of medium and high complexity technological resources in municipal healthcare; the 
effort spent on primary healthcare; and, finally, the exposure time of municipal governments to left or center-left parties. A sixth hypothesis was added regarding the association of the dependent variable with allocation to other budgetary functions of health interest in the municipalities. Thus, a linear regression model with mixed panel effects for the period 2008-2017 was built for the test.

The article is organized into four sections, in addition to this introduction and the final considerations. The objective is presented in the next section, the linking of a municipality's own local revenues to healthcare expenses, based on the discussion of how Brazilian fiscal federalism affects the implementation of social policies. Next, the research problem and the working hypotheses are defined in the second section. The empirical approach strategy to the problem is presented in the third section in order to justify the methodological choices, including the operationalization of the variables and construction of the analysis models. The fourth section focuses on the results and analyzes that support the final conclusions.

\section{Federalism and fiscal regulation of subnational governments}

The establishment of a constitutional minimum for expenses incurred using own revenues for healthcare, under Constitutional Amendment 29/2000, was not an isolated decision. It is part of a fiscal federalism arrangement built in recent decades to deal with the need to match allocative functions with distributive and stabilizing ones. In fiscal federalism, these functions could be in conflict: the autonomy to choose the destination to the revenues (allocative function) not only could affect the redistributive capacities or the power to reduce social and regional inequalities, but also compromise economic stability (Silva, 2005), for example when aggravating public indebtedness. The more decentralized federalism, the greater the potential conflict between those fiscal functions.

Federalism presupposes the maintenance of some degree of decision-making diversity given that it is a system which distributes the political authority of the State across multiple centers which are defined and ordered territorially (Elazar, 1987), so the allocative function depends upon the distribution of attributes between levels of government. On the other hand, social welfare policies assume equalization in offers which provide social guarantees on a national scale (Obinger, 2005; Greer, 2010). So, the option to privilege allocative function under local decisionmaking diversity could cause variations in the local provision of services and cause internal imbalances in the flow of beneficiaries and in the distribution of tax charges (race to the bottom), jeopardizing the nationally egalitarian nature of the provision of social services. Central governments generally build fiscal instruments to make allocative and redistributive functions compatible, while preserving the stability of the economic system (Oates, 1999; Silva, 2005; Rezende, 2010). These instruments may include centralized schemes in the federal government for the financing of social policies, the complementation of local spending by the central government until reaching a national standard or even "earmarking" or reserving a proportion of the revenues of state and municipal governments for those policies (De Mello, 2003).

Regarding fiscal decentralization, it is worth remembering that the Brazilian Constitution expanded taxing powers for states and municipalities, while also expanding the base of mandatory free transfers from the Federal government to these levels of government, especially through the Member States' Participation Fund (FPE) and the Municipality Participation Fund (FPM), making the latter the biggest net earners in terms of participation in public revenue. For example, the participation of municipalities in available public revenue rose from $13.3 \%$ to $17.3 \%$ between 1988 and 2004 , while that of the states fluctuated from $26.6 \%$ to $25.3 \%$, and that of the Federal government fell from $60.1 \%$ to $57.4 \%$ (Afonso, 2006). Recent data (IFI, 2018) show that, despite collecting $2.1 \%$ of GDP in 2017, their available revenues for municipalities more than tripled to $6.6 \%$ of GDP after receiving transfers from the central government and states.

But, on the other hand, fiscal decentralization has been combined with mechanisms for regulating subnational governments by the Federal government, structured with the purpose of enabling national policies 
and ensuring macroeconomic stability. Therefore, if the decentralization of responsibilities and resources to states and municipalities for different social policies "meant different things and occurred at different rates, according to the specific design of each policy" (Almeida, 2005, p. 37), then the Federal government assumed an important role in the federative coordination of most of them (Abrucio, 2005), so that different legal-institutional mechanisms resulted in expanding municipal expenditure and the supply of services (Vazquez, 2011)

It is true that the scenario was unfavorable in the first years after 1988 because on the one hand, subnational governments were not legally obliged to reserve part of their budget revenues to meet the new responsibilities, and on the other hand, the Federal government had lost a substantial part of resources and decreased its policy-inducing capacity. However, when using constitutional prerogatives to legislate fiscal and administrative behavior of subnational governments (Arretche, 2012), the Federal government recovered an important part of the revenue lost in the early 1990s. More specifically, it recovered its revenue power through social contributions and by an economic domain whose creation was its exclusive tax prerogative and generated resources which were not necessarily shared with states and municipalities. By restoring its capabilities, the Federal government started to induce policies through conditional intergovernmental transfers.

In addition, in order to preserve the stabilizing function, ensuring levels of fiscal balance which would remove inflation risks after the "Real Plan" (Plano Real), the Federal government began to restrict the autonomy of subnational governments over public finances through two strategies: 1) fiscal adjustments by states and municipalities as a condition for debt renegotiation with the Federal government; 2) approval of the Fiscal Responsibility Law (Law 101/2000), which conditioned government expenditure to its capacity of collecting taxes (Oliveira, 2010). It should also be noted that the creation of the Social Emergency Fund, later renamed Untying Federal Revenues (Desvinculação das Receitas da União DRU) in the 2000s, retained a considerable part of the transfers which were previously mandatory to states and municipalities (Arretche, 2012). More recently in 2016, around $30 \%$ of all federal taxes and social contributions have been released from mandatory transfers to states and municipalities, in favor of the investment of the Federal government in other expenses considered as priority and in the commitment to compose high primary surpluses.

Therefore, despite the fiscal decentralization degree in the country (Afonso, 2006), especially when compared to other Latin American countries (Falleti, 2005), the fiscal regulation exercised by the Federal government has the means to reduce the threat of diverging choices by states and municipalities on the integrity of constitutionalized national policies. The design of decentralization under Brazilian federalism after 1988 moved towards centralizing the formulation (policy decision-making) of social policies and decentralizing implementation (policy making) (Arretche, 2012). Associated with budgetary constraints resulting from economic choices, this design resulted in higher levels of effort by local governments as entities closer to the population's healthcare needs. It is important to highlight that, articulated to the states, the municipalities progressively assumed the management of health services while the Ministry of Health assumed a strategic role in the formulation of health policies (Massuda, 2020).

In the constitutional and legal system of Brazilian federalism, the decentralization of management was accompanied by the provision of mechanisms for direct and automatic transfer of resources from the National Health Fund (Machado \& Guim, 2017). That way, municipalities, to fulfill the new constitutional responsibilities, started to depend on their adhesion to conditional transfers coming from the Federal government (Oates, 1999), a mechanism which strongly boosted the structuring of social policies in Brazil (Abrucio, 2005; Almeida, 2007; Vazquez, 2011; Arretche, 2012). However, the instability brought about by the lack of definition of permanent sources of resources for healthcare under the Constitution and the Organic Health Law (Menicucci, 2009) showed that it was necessary to define more precise responsibilities and earmarking was presented as an alternative for the sector's financing (De Mello, 2003). 
In contrast to education, which received support from constituents for the earmarking of $25 \%$ of revenues from States and Municipalities and 18\% from the Federal government to the sector, healthcare did not initially achieve the same success in ensuring public revenues for the implementation of the Unified Health System (SUS). This was only possible on December 13, 2000, when a constitutional basis was established for the responsibilities of the three levels of government for healthcare financing, bringing regularity into the contribution of resources (Scatena et al., 2009). Thus, there was an $89 \%$ expansion in per capita healthcare expenditure in Brazil between 2000 and 2010 (Piola et al., 2016). Local governments now had as main sources of resources: the municipality's own revenues (sum of resources from municipal taxation plus those from mandatory transfers from the Federal and State governments); and conditional transfers, fund by fund, from the SUS.

Referring to the first source, the expenditure earmarking means mandatory destination of some proportion to a particular demanding, like Public Health (Cashin et al., 2017). But there are arguments for and against the use of expenditure earmarking. In favor, earmarking may guarantee founding for government priorities that could be neglected; against, earmarking may introduce rigidities in budget process to the point of becoming a procyclical instrument, contributing to increase revenues during times of economic expansion and decrease during economic downturns (Cashin et al., 2017).

Two aspects draw attention to municipal health expenditures performed through earmarking in Brazilian case. First, according to data from the Public Health Budget Information System (Siops), a municipal's own revenues guaranteed the main source of municipal resources for healthcare between 2005 and 2018, oscillating around $60 \%$ of these over the course of the period. Second, suffering the impact of local taxation on its formation, this revenue source is deeply affected by regional inequalities and asymmetries in population scale between municipalities. Thus, the implications of implementing the Constitutional Amendment 29/2000 for healthcare expenditure conducted by different levels of government are discussed in the next section, emphasizing the case of municipalities.

\section{Hypertrophy of municipal expenditure}

As already noted, the earmarking of a constitutional minimum for allocating municipalities' own resources for healthcare would play an important role in constraining government entities to commit to SUS implementation. Regarding the established obligations, in the year 2000 the Federal government should have spent the corresponding to that amount allocated in 1999 , but increased by $5 \%$, and from that point to correct this amount by the positive variation of the Gross Domestic Product (GDP) in consecutive years. Furthermore, the definition for states and municipalities was even clearer: while the former should allocate $12 \%$, the latter should allocate a minimum of $15 \%$ of their own revenues. Everyone should observe the rules regarding the classification as "health expenses", originally established by Resolution 322/2003 of the National Health Council and subsequently by Complementary Law 141/2012.

In relation to expenses incurred with conditional transfers, it is important to remember that ministerial ordinances regulated each modality of these establishing specific purposes and conditions for the use of resources until Ministerial Ordinance 399/2006 created the financing blocks, grouping them and allowing reallocations of leftovers within each block. That change represented a limited flexibility to allocate expenses, as it maintained the various SUS modalities for transferring federal resources, maintaining, some of them under specific requirements for execution and accountability.

Resuming the implementation of Constitutional Amendment 29/2000, a transition period in which a minimum of $7 \%$ of states' and municipalities' own revenues allocated to healthcare in 2000 was foreseen to reach the respective minimums of $12 \%$ and $15 \%$ by 2004 . However, the starting points were already very different in 2000: while states allocated $7.2 \%$, municipalities already used up about $13.7 \%$ of their own revenue for healthcare expenses (Piola et al., 2016), already close to the constitutional minimum, and in 2002 it reached 16,5\% according to Siops data, 
exceeding the minimum established even before the transition period. The trajectories were also quite different in terms of speed and available resources. The state average had not reached $12 \%$ by 2008 , but six years earlier (in 2002), municipalities had al ready exceeded an average of $17 \%$ of their own revenues allocated to the sector (Piola, 2017). This trend continued in the following years, with municipalities reaching a national average of $22.9 \%$ in 2018 , while states allocated $13.0 \%$ on average, according to Siops data. In terms of relative participation, the EC 29 brought about significant changes in the relative participation of each government level to public health financing between 2000 and 2006 . The Federal government decreased its stake from $60 \%$ to $48 \%$; the states increased their participation from $18 \%$ to $25 \%$; and the municipalities went from $22 \%$ to $28 \%$ (Vazquez, 2011).

Thus, considering that expenditure earmarking is intended to compel government entities to allocate public revenues at levels which spontaneously would not be reached, it deserves an explanation that the evolution of municipal expenditure on healthcare using their own revenues got, on average levels, significantly above the required minimum. However, it should also be noted that according to Siops data for 2018, there were variations in the percentages of municipalities's own revenues allocated to healthcare depending on their region of insertion and their population size, despite the low amplitude in these variations. The averages in the first case varied between $24.2 \%$ (in the Southeast) and 20.8\% (in the North). For population size, the variations were between $24.7 \%$ (for the range between 200 and 400 thousand inhabitants) and $20.4 \%$ (for municipalities in the range of up to 5,000 inhabitants). Figure 1, however, offers an evolutionary perspective of over-allocation between 2000 and 2015, with intervals of five years, considering different ports in the municipalities. Only in 2000 the medians were below the constitutional minimum, which happened for all population groups. In 2015, at the end of the series, the medians were above $20 \%$ as well as the first quartile was clearly above $15 \%$ also for municipalities of all population groups, demonstrating that not only the averages, but also the concentration by level of expenditure on municipalities's own revenues are well above the mandatory $15 \%$.

Studies on the effects of Constitutional Amendment 29/2000 (Scatena et al., 2009; Silva et al., 2012. Piola et al., 2016) have generally provided a descriptive treatment for this phenomenon, and studies which propose an analytical and explanatory exploration to identify factors that have put pressure on the increase in health expenditure (Araújo et al., 2017) are rare. Furthermore, the fact that the Federal Constitution of 1988 defined health as "the right of all and the duty of the State" (article 196) cannot be overlooked, to be ensured through social and economic policies which lead to " $a$ reduction in the risk of disease and other damages and universal and equal access to actions and services for their promotion, protection and recovery" (BRASIL, 1988), which means that their guarantee also depends on the allocation of other budgetary functions which impact its promotion. Considering this point, higher allocation levels of the government's health revenues could not necessarily favor healthy populations if accompanied by low allocation levels to other budgetary functions such as basic sanitation or sports and leisure.

In addition, studies referring to the increase in the revenue allocation specific to municipalities to healthcare have addressed this phenomenon in average terms, as we have done so far. That is to say, they present the average of the percentages by the region or size of the municipality, which ends up hiding the fact that despite practically all Brazilian municipalities allocated at least $15 \%$, there are those which allocate more than $30 \%$. For example, there were municipalities that allocated much smaller proportions in 2018, such as Mesquita - MG (15.0\%), or very big such as João Pinheiro - MG (with 35.0\%) (Siops, 2019).

Considering this fact, we assume herein that the factors which explain the great variations in these proportions, and particularly those present among those with the highest expenditure, can contribute to explain the overallocation of expenses by pulling the averages of municipal expenditure on healthcare up.

\section{Explanatory factors for overallocation of expenses}

Two questions guided this study: (1) what factors explain the overallocation of expenses on healthcare 
Figure 1 - Overallocation Boxplot By Municipality Population Size, Brazil, 2000-2015.

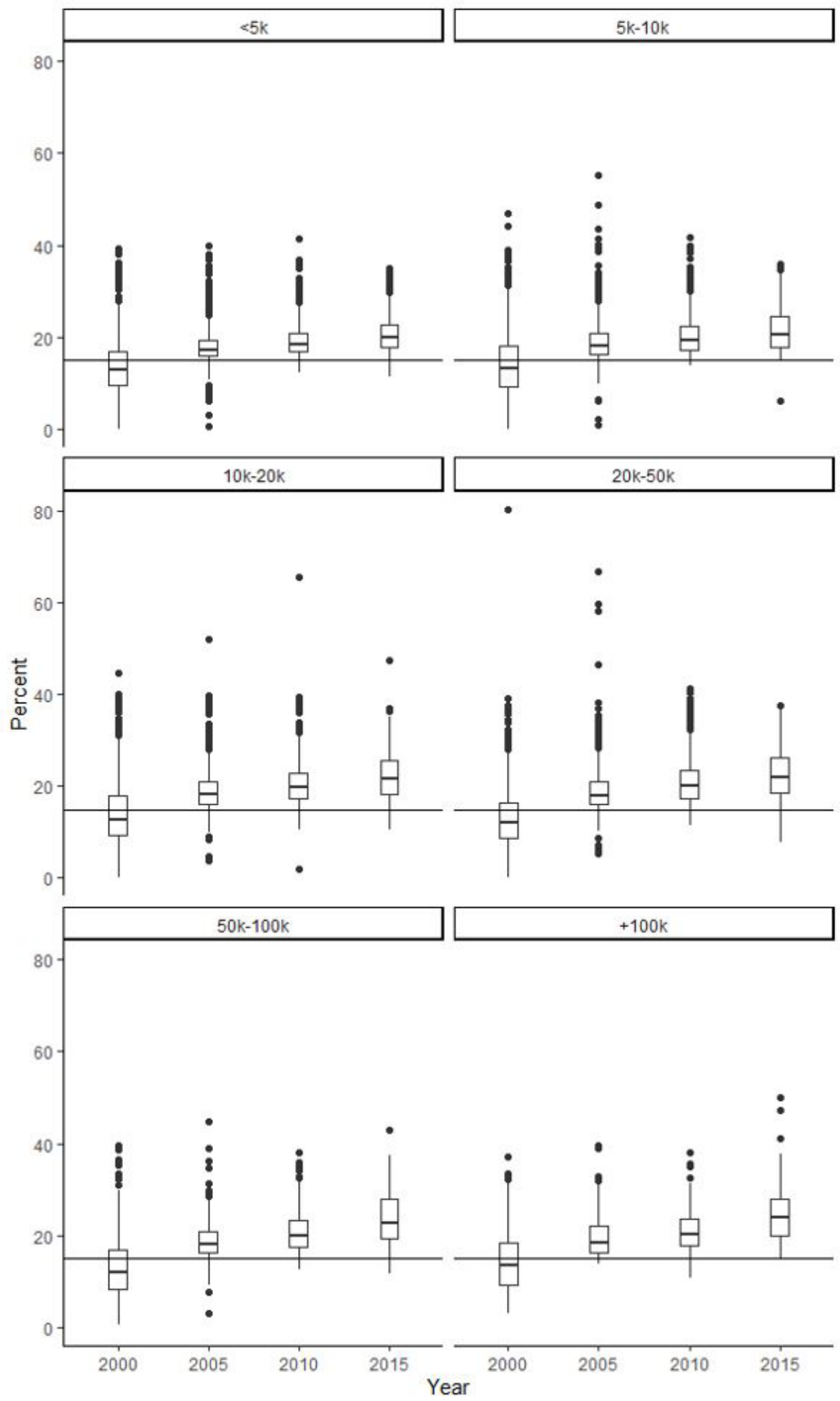

Source: Siops, 2000-2015. 
by Brazilian municipalities using their own revenues considering the constitutionally required minimum?; (2) has the overallocation of health expenditure been accompanied by restrictions on expenditure levels in other government areas, which are also of interest in guaranteeing the right to healthcare?

Regarding the possible answers to the first question, we first of all suspect the pressure exerted by the loss of economies of scale on local health expenditure in the municipalities with small populations. This would be a considerable problem because it is a universal policy in which more than $70 \%$ of government implementing entities have up to 20 thousand inhabitants. Losses of economy of scale in the production of public services in small municipalities have given rise to several studies in other countries (Di Porto et al., 2017; Niaounakis \& Blank, 2017; Allers \& De Greef, 2018), although less in Brazil, where few studies have explored the theme and with a greater focus on the health sector (Iunes, 1995; Mendes, 2001; Mattos et al., 2010). In a cross-sectional study for the year 2010, Machado and Guim (2017) found a relationship between population scale and per capita expenditure on personnel, basic medicines and capital.

Still regarding the first question, a second factor concerns the regional insertion of the municipalities considering different degrees of economic and social development. The regional development level can impact the municipalities' own taxation capacity, and hence on the availability of revenues to allocate to healthcare services. Machado and Guim (2017) reported that municipalities in the South, Midwest and Southeast had their own per capita revenues of $\mathrm{R} \$ 2,234.19, \mathrm{R} \$ 2,142.85$ and $\mathrm{R} \$ 2,066.83$ in 2010 , respectively, while these amounts in the municipalities in the North and Northeast were R\$1,600.71 and $\mathrm{R} \$ 1,448.30$. In the same direction, Piola et al. (2016, p. 416) concluded that "the Southeast region is the one with the highest values, the Northeast region the lowest, and the Midwest, North and South regions occupy intermediate positions" after analyzing the per capita allocation of their own health revenues between 2000 and 2010. Regional inequalities also impact the regional distribution of healthcare resources, with Póvoa and Andrade (2006) finding a higher concentration of doctors, hospital beds and other resources for providing services of greater technological complexity in the more developed regions.

A third explanatory factor would be the degree of incorporation of medium and high complexity technological resources in healthcare by the municipalities, since these may vary within the same region. Unlike other sectors of the economy, an aggregation of specialized human resources, as well as equipment and other inputs does not produce cheaper products offered in healthcare, and the incorporation of new technologies is cumulative and not substitutive, since it adds new devices to previous technologies (Vianna et al., 2005). Piola (2017) noted that about $66 \%$ of the total transfers from the SUS to states and municipalities between 2011 and 2014 were destined for medium and high complexity procedures, which points to the large space occupied by the technological incorporation in the expenses of local health systems. However, it is possible that these transfers

since they are insufficient, they end up inducing increasing counterparts by municipal managers for their maintenance, meaning that they end up inducing higher levels of their own revenue expenditure. (Araújo et al., 2017, p. 962)

This phenomenon would be even more aggravated in the case of those municipalities which assume a reference role or pole in serving other municipalities in the same health region, since "their physical and financial limits of regional reference may also be insufficient to cover expenses with medium and high complexity procedures, requiring a greater share of their own resources" (Araújo et al., 2017, p. 962). Thus, municipalities which concentrate more hospital beds or that assume the role of regional reference would not only receive higher SUS transfer levels, but they would also be more pressured to allocate expenses with their own revenues in the sector.

Still on the first question, a fourth factor which could negatively impact municipal health expenditures would be the local investment in primary healthcare, considering its potential to solve health problems before cases require more complex procedures. 
Basic healthcare could assume a structuring role, as "care coordinator and organizer of actions and services available on the network" (Brasil, 2017). Starfield (2002) presented several studies which dealt with the impact of primary healthcare on the capacity of healthcare systems to solve problems, finding more negative effects on those systems guided by a tendency to specialize in healthcare. That way, municipalities with higher levels of investment or resolution in primary healthcare would suffer less pressure to carry out procedures of greater technological complexity, presenting lower expenditure levels of their own revenues on healthcare. But there are works that suggest an opposite relationship between these variables: if on the one hand primary healthcare can reduce hospital admissions, on the other it tends to increase the access to other modalities of services (Massuda, 2020), that demand more expenditures. Moreover, insufficient funding through SUS transfers (Fausto et al. 2018) and the absence of counterparts from the states put pressure on municipal spending on primary care, especially for the expansion of family health teams (Silva, 2017). So, in a negative or positive way, primary attention effort can be related to municipal expenditure by own sources.

Still on the first question, a fifth and final factor would be the political-ideological alignment of the municipal manager. This factor is still little explored in studies on Brazilian healthcare policy, and drives the idea that center-left or left parties present higher levels of investment in social policies (Obinger et al., 2005), as well as that right and center-right parties value fiscal balance to the detriment of social spending. However, it should be noted in this regard that previous studies related to the theme (Rodrigues, 2007; Ribeiro, 2013) did not identify significant effects between the alignment of city halls to left-wing parties and the allocation of expenses on social policies.

Considering the expected relationships between the five factors considered and the dependent variable, namely per capita expenditure using their own health revenues, we assume the following as hypotheses:

1. Per capita expenditure using a municipality's own revenues on healthcare negatively varies with its population scale;
2. Per capita expenditure using a municipality's own revenues on healthcare positively varies with its level of regional economic and social development;

3. Per capita expenditure using a municipality's own revenues on healthcare positively varies with its incorporation degree of medium and high complexity technological resources in healthcare;

4. Per capita expenditure using a municipality's own revenues on healthcare negatively varies with its effort spent on primary healthcare;

5. Per capita expenditure using a municipality's own revenues on healthcare positively varies with the exposure time of its governments to left or center left parties.

As for the second question of this work about possible restrictions on other governmental areas relevant to guaranteeing the right to health produced by the overallocation of their own revenues to healthcare expenditure, we start from Starfield (2002) notes on the complexity in healthcare production:

The chain of causes is complex. It involves antecedent factors such as the environmental context, social conditions and social relationships, and genetic risk factors. Some of these factors operate directly (such as contaminated water or risk factors for safety at home) and some indirectly through mediation factors involving behavior, social stress and access to medical care. All risks interact in various ways (many of which are unknown) in their effect on health. (Starfield, 2002, p. 23)

The healthcare of the populations also depends on the allocation of expenses to other budgetary functions which condition access to basic material goods such as water, or even immaterial ones such as access to education or leisure. On the other hand, it is known that while part of the municipal budgetary functions, especially health and education, are regulated by federal legislation (Arretche, 2012), 
other functions such as basic sanitation and sports and leisure (for example) are not free for local governments to allocate resources according to their preferences. The allocative behavior of these governments, as identified by the author, "was high priority and low inequality in regulated policies, accompanied by low priority and high inequality in unregulated policies" (Arretche, 2012, p. 611). Considering that budget revenues are a fixed amount each year, it would be plausible to assume that municipalities with a higher proportion committed to healthcare expenditures suffer greater constraint in allocations to other areas of interest in health promotion, such as basic sanitation actions or sports and leisure. Hence, we consider a sixth hypothesis:

6. Higher levels per capita expenditure on healthcare performed using their own revenues are negatively associated with the allocation levels in other budgetary functions of health interest.

The next section describes the methodological procedures adopted in this study to verify these hypotheses and to therefore answer the previously proposed questions.

\section{Methodology}

The expenditure analysis by Brazilian municipalities using their own revenues on healthcare and possible explanatory factors covered the period between 2008 and 2017. Two limitations of this time horizon were the availability and compatibility of information sources, especially for years prior to 2008, which refers to data on hospital admissions. In addition, 2018 was excluded due to the number of pending issues verified in some of the databases fed by the municipalities, especially tax data.

The option to conduct a longitudinal panel study and to test the hypotheses were chosen, and progressive longitudinal models were developed. Thus, new variables were gradually incorporated in order to increase the explained variance of expenditure per capita using the municipalities' own revenues. Due to parsimony, only the full model is presented in the next section. In addition, it was decided to estimate a series of linear regression models with mixed effects considering both random and fixed effects to understand this variance. In panel models in which trends are analyzed for a period of ten years, as in the case of this study, this option enables analyzing the intraclass correlation.

The random effect was determined by the "year" variable and the assumption made that each analysis unit (municipality) can have its own performance in terms of expenditure allocation, not all necessarily starting from the same average expenditure or following the same trend over time. Thus, the individual variance of each municipality was incorporated into the analysis. These variances were deflated to current values using the General Price Index of the Getúlio Vargas Foundation (IGP/FGV) in order to allow a comparison of the values between 2008 and 2017. Thus, the "deflate" package of the $\mathrm{R}$ programming languagewas used (Meireles, 2018).

Three estimates were performed on how to incorporate the time variable (as null, as fixed and as random) in the analysis of per capita expenditure on healthcare using municipalities' own resources between 2008 and 2017 for purposes of adjusting the model. Finally, we chose to incorporate it as a random variable, which allowed the model to capture a higher level of intraclass variability.

Four data sources were used to feed the variables articulated under the different hypotheses:

- The Public Health Budget Information System (Sistema de Informaçōes sobre Orçamentos Públicos em Saúde - Siops);

- The Survey of Basic Municipal Information (Pesquisa de Informaçōes Básicas Municipais Munic $)^{2}$;

- The SUS Hospital Information System (Sistema de Informaçôes Hospitalares do SUS - SIH-SUS);

- The Finances of Brazil (Finanças do Brasil - Finbra) / Accounting and Tax Information System for the Brazilian Public Sector (Sistema 
de Informaçóes Contábeis e Fiscais do Setor Público Brasileiro - Siconfi) .

The details of the variables that were fed from each of these sources are shown in Table 1:

Two sources of the information mentioned in Table 1 deserve further details. The ICSAP variable is Hospitalizations for Conditions Sensitive to Primary Healthcare. The classification by Alfradique et al. (2009) was used, being a similar strategy to that of other studies with similar themes (Pinto et al., 2019). To calculate the ratio between hospitalization and population, the resident population of the municipality was initially used regarding the reason for high and medium complexity admissions in the municipality and the population, as suggested by other authors (Paschoalotto et al., 2018). However, the estimates suffered from the concentration of hospitalizations in small municipalities. Municipalities with a small population size in some states eventually concentrated hospitalizations in the surrounding municipalities, functioning as small hospital centers and presenting a high rate of hospitalizations per population. The solution found herein was to use the state's population as a proxy, which controlled the population size of the municipalities and enabled identifying the municipalities with the highest technological concentration in the state.

A limitation of this work is the lack of information declared on municipal expenditure in some specific years. Table 2 contains the total number of municipalities existing in the reference year, the total number of municipalities in the database after excluding those who did not have some of the information in Table 2, and the proportion of municipalities which made up the study in each of the years. This proportion varied between $92.80 \%$ in 2014 , and $99.19 \%$ in 2009. Nonetheless, it is believed that this work brings important conclusions despite this limitation.

\section{Results and Discussion}

Figure 2 shows the spatial evolution of the annual averages of Brazilian municipalities per capita expenditure using their own revenues on healthcare for the analyzed period, in which it is notable that in addition to the increase in averages over time, the differences between macro-regions are maintained and may be increasing. Two observations are necessary. First, the figures for 2011 were not included in Figure 2 to facilitate data visualization, but this information is included in the models. Second, the blank values in Figure 2 refer to municipalities which did not have information in Siops for that period.

The figures referring to the per capita municipal expenditure using their own revenues on healthcare between 2008 and 2017 presented a clear separation between the Center-South of the country and the North and Northeast. The largest expenses per capita in the Center-South region were concentrated, represented by the warmer tones of the figure. The tones become more intense in the country as a whole in subsequent years, mainly advancing in the Midwest region, whose pattern came closer to the South and Southeast. On the other hand, the tones remain softer in the North and Northeast despite the increase in spending in some states.

Table 3 details the municipalities' growth in per capita healthcare expenditure using their own revenues. The average, which was $\mathrm{R} \$ 359.67$ in 2008 , reached $\mathrm{R} \$ 480.27$ at the end of the period, with a positive variation of $33 \%$. This variation was even greater for the median, which is less sensitive to extreme cases, reaching a growth of approximately $38 \%$. If such differences in variation between mean and median suggest an increase in inequality, the analysis of averages for the first and third quartiles, meaning of the $25 \%$ municipalities with the lowest and highest expenses in the country, shows that the variation in the values of the first was about $26 \%$, while that of the third was more than $37 \%$. The increased intensity in expenditure per capita between the two quartiles was asymmetric over time, with municipalities with higher allocation levels expanding their respective health budgets even more than the ones made by those with lower levels, which confirms the increase in inequalities.

A possible analysis before we explore the longitudinal models is to aggregate the municipalities regarding their expenditure per capita on health with their own revenues. This topic is addressed in the first 


\section{Table 1 - Variables and Data Sources for Analyzing Municipal Expenditures Using Their Own Revenues on Healthcare.}

\begin{tabular}{|c|c|c|}
\hline Data source & Variables & Information \\
\hline \multirow{3}{*}{ Siops } & Own revenue expenditure on healthcare & $\begin{array}{l}\text { Dependent variable in this research. It presents the } \\
\text { municipality's expenditure with their own revenue on } \\
\text { healthcare as declared to Siops. }\end{array}$ \\
\hline & Region where the municipality is located & $\begin{array}{l}I B G E \text { regional division: North; Northeast; Southeast } \\
\text { (reference); South; and Midwest. }\end{array}$ \\
\hline & Population size of the municipality & $\begin{array}{l}\text { Six categories of population size: up to 5,000 inhabitants; } \\
\text { between } 5 \text { and } 10 \text { thousand inhabitants; between } 10 \text { and } \\
20 \text { thousand inhabitants; between } 20 \text { and } 50 \text { thousand } \\
\text { inhabitants; between } 50 \text { and } 100 \text { thousand inhabitants; } \\
\text { and over } 100 \text { thousand inhabitants. }\end{array}$ \\
\hline \multirow{4}{*}{ Munic } & Mayor's gender & $\begin{array}{l}\text { Gender was dichotomized between male (reference) and } \\
\text { female. }\end{array}$ \\
\hline & Mayor's education level & $\begin{array}{l}\text { Education divided into six categories: incomplete } \\
\text { primary school; complete primary education; incomplete } \\
\text { high school; complete high school; incomplete higher } \\
\text { education; and complete higher education (reference). }\end{array}$ \\
\hline & Age & $\begin{array}{l}\text { The mayor's age divided between six categories: between } \\
20 \text { and } 30 \text { years (reference); between } 30 \text { and } 40 \text { years; } \\
\text { between } 40 \text { and } 50 \text { years; between } 50 \text { and } 60 \text { years; } \\
\text { between } 60 \text { and } 70 \text { years; and over } 70 \text { years. }\end{array}$ \\
\hline & Ideological spectrum of the mayor's party & $\begin{array}{l}\text { Classification of the mayors' parties: left; center-left; } \\
\text { center-right (reference); right; other. }\end{array}$ \\
\hline \multirow[b]{2}{*}{ SIH } & ICSAP & $\begin{array}{l}\text { Hospitalizations for conditions which are sensitive to } \\
\text { Primary Healthcare in the municipality. }\end{array}$ \\
\hline & Hospitalizations & $\begin{array}{l}\text { Ratio between high and medium complexity } \\
\text { hospitalizations in the municipality and resident } \\
\text { population in the state, per thousand inhabitants. }\end{array}$ \\
\hline \multirow{7}{*}{ Finbra / Siconfi } & Primary Healthcare & $\begin{array}{l}\text { Municipal expenditure using its own resources on } \\
\text { primary healthcare. }\end{array}$ \\
\hline & Hospital Care & $\begin{array}{l}\text { Municipal expenditure using its own resources on hospital } \\
\text { care. }\end{array}$ \\
\hline & Health Surveillance & $\begin{array}{l}\text { Municipal expenditure using its own resources on health } \\
\text { surveillance. }\end{array}$ \\
\hline & Employment & $\begin{array}{l}\text { Municipal expenditure using its own resources on } \\
\text { employment. }\end{array}$ \\
\hline & Primary School & $\begin{array}{l}\text { Municipal expenditure using its own resources on } \\
\text { primary education. }\end{array}$ \\
\hline & Sanitation & $\begin{array}{l}\text { Municipal expenditure using its own resources on } \\
\text { sanitation. }\end{array}$ \\
\hline & Sport and Leisure & $\begin{array}{l}\text { Municipal expenditure using its own resources on sport } \\
\text { and leisure. }\end{array}$ \\
\hline
\end{tabular}

Source: Authors' own elaboration.

graphic of Figure 3, elaborated in another paper (Machado et al., 2020).

We observe three main clusters: the CenterNorth, the Center and the Center-South. The former represents the lower mean of per capita expenditures and less growth in the period studied. The CenterNorth cluster occupies a relatively larger area regarding its own expenses, which includes part of 
Figure 2 - Municipal Per Capita Expenditure Using Their Own Revenues on Healthcare, Brazil, 2008-2017.
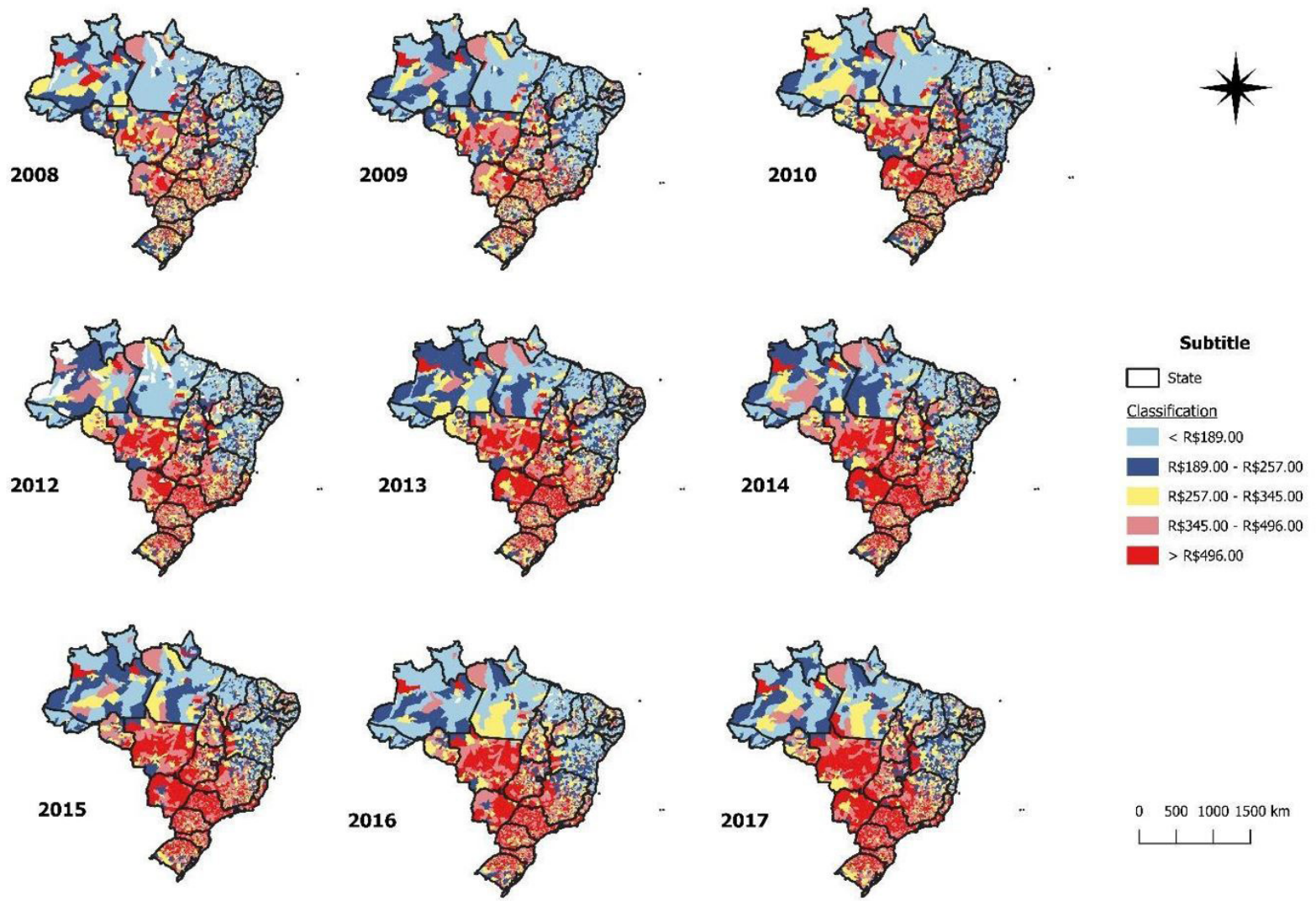

0 $50010001500 \mathrm{~km}$

Source: Siops, 2008-2017.

Figure 3 - TER for Municipal Expenditure Per Capita on Health with Their Own Revenues and Total, Brazil, 2005-2015.
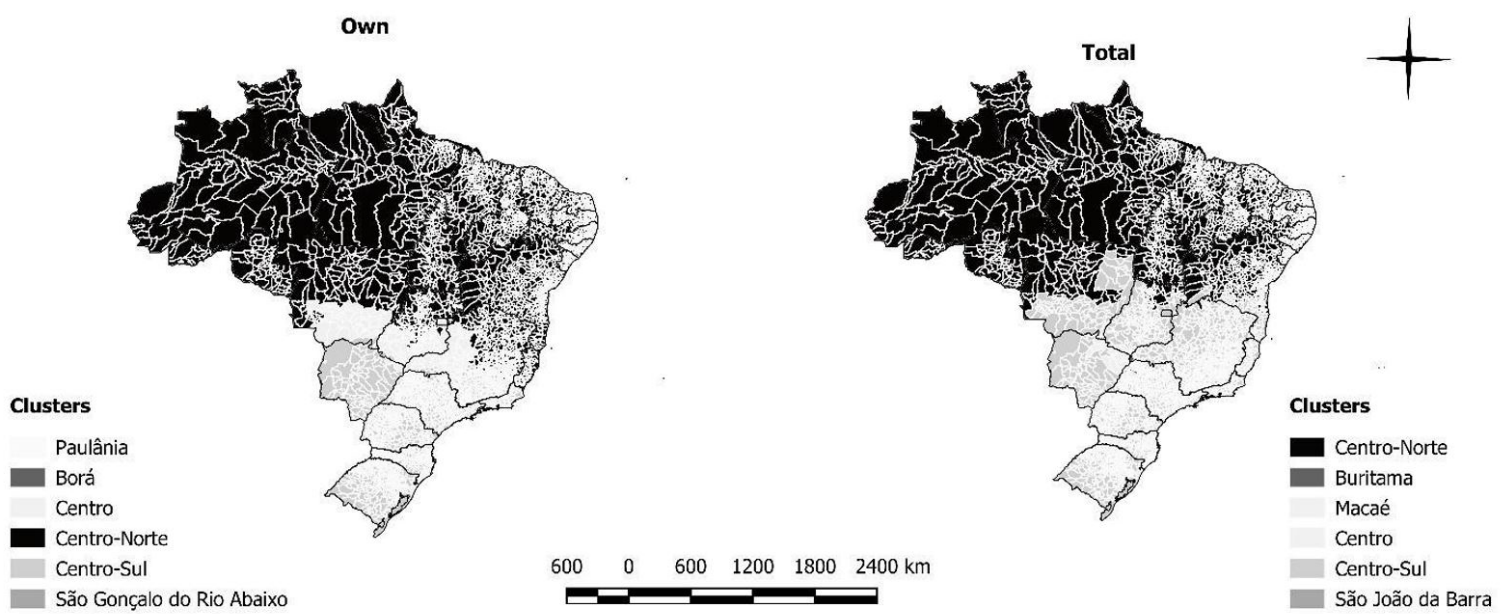

Source: Machado, Quaresma e Araújo (2020). “Municipal expenditures using own revenues and resilience of territorial inequalities in health". 
Southeast in Brazil (Espírito Santo state and much of Minas Gerais). The Center-South has a higher mean and growth than the previous one and covers Rio de Janeiro, almost all of São Paulo and Mato Grosso do Sul, as well as the south of Minas Gerais. The Cluster Center constitutes a transition zone that has the highest average expenditure per capita, although its growth in the period studied does not exceed that of the South Center and covers in the south of Mato Grosso and Goiás and west of Minas Gerais, complemented with patches in the north of São Paulo.

Table 2 - Central Measures and Quartiles of Per Capita Municipal Expenditure Using Their Own Revenues on Healthcare Between Brazilian Municipalities Between 2008 and 2017.

\begin{tabular}{cccc}
\hline Year & Database & Existing & Percentage \\
\hline 2008 & 5,482 & 5,565 & $98.51 \%$ \\
\hline 2009 & 5,520 & 5,565 & $99.19 \%$ \\
\hline 2010 & 5,495 & 5,565 & $98.74 \%$ \\
\hline 2011 & 5,384 & 5,565 & $96.75 \%$ \\
\hline 2012 & 5,175 & 5,570 & $92.91 \%$ \\
\hline 2013 & 5,389 & 5,570 & $96.75 \%$ \\
\hline 2014 & 5,169 & 5,570 & $92.80 \%$ \\
\hline 2015 & 5,394 & 5,570 & $96.84 \%$ \\
\hline 2016 & 5,344 & 5,570 & $95.94 \%$ \\
\hline 2017 & 5,453 & 5,570 & $97.90 \%$ \\
\hline
\end{tabular}

Source: Authors' own elaboration based on Finbra / Siconfi, 2008-2017.
The analysis regarding longitudinal models of municipal per capita expenditure using their own revenues on healthcare is presented in Table 4. The final full model contains the controls according to time; the mayor's characteristics and ideological position of their respective parties; general data from the municipality, such as region and population size; profile of hospital care; in addition to other functions and sub-functions of municipal expenditure.

The first hypothesis of the study was corroborated. Taking the population range of the municipalities above 100 thousand inhabitants as a reference, a negative relation was verified in relation to the impact of the population scale of the municipalities on per capita expenditure using their own revenues on healthcare. Although this result can be generally attributed to the loss of economy of scale in the production of services in small municipalities, considering that practically $70 \%$ of Brazilian municipalities have a maximum of 20 thousand inhabitants, it is also possible that the data reflect extra expenditure on medical remuneration as a strategy to attract and retain this workforce on the part of those furthest from large urban centers. At this point, it is important to remember that expenditure on the payment of personnel and social charges represents about three quarters of the total expenditure of municipalities on healthcare (Araújo et al., 2017), and that the shortage and poor geographical distribution of doctors has remained a severe and persistent problem in Brazil (Stralen et al., 2017).

Table 3 - Central Measures and Quartiles of Municipal Expenditure Per Capita Using Their Own Revenues on Healthcare Between Brazilian Municipalities Between 2008 and 2017.

\begin{tabular}{ccccccc}
\hline \multirow{2}{*}{ Year } & \multicolumn{7}{c}{ Estimates } \\
\cline { 2 - 7 } & Min. & 1st Qu. & Median & Mean & 3rd Qu. & Max. \\
\hline 2008 & 7.03 & 206.44 & 297.90 & 359.67 & 442.42 & 2866.01 \\
\hline 2009 & 0.10 & 198.87 & 299.88 & 357.64 & 445.39 & 2964.61 \\
\hline 2010 & 16.02 & 213.49 & 322.56 & 384.43 & 475.57 & 2862.74 \\
\hline 2011 & 5.21 & 231.59 & 347.74 & 416.20 & 518.00 & 3085.11 \\
\hline 2012 & 34.99 & 240.12 & 371.46 & 443.13 & 552.50 & 3406.61 \\
\hline 2013 & 54.08 & 248.45 & 382.65 & 452.00 & 567.81 & 3584.16 \\
\hline 2014 & 27.34 & 255.38 & 399.20 & 471.84 & 589.93 & 3529.78 \\
\hline 2015 & 35.91 & 255.71 & 399.81 & 472.30 & 600.82 & 3457.13 \\
\hline 2016 & 65.52 & 246.36 & 384.96 & 453.39 & 570.67 & 2864.94 \\
\hline 2017 & 69.04 & 259.24 & 411.92 & 480.27 & 607.68 & 3038.00 \\
\hline
\end{tabular}

Source: Siops/Datasus, 2008-2017. 
Table 4 - Longitudinal Models of Municipal Expenditure Per Capita Using Their Own Revenues on Healthcare.

\begin{tabular}{|c|c|c|}
\hline Variables & Category & Coefficient \\
\hline Mean Intercept & - & 305.2816 \\
\hline Year & - & 8.0980 \\
\hline \multirow{2}{*}{ Gender } & Male & Reference \\
\hline & Female & -1.7049 \\
\hline \multirow{6}{*}{ Education } & Incomplete Primary School & 1.8773 \\
\hline & Complete Primary School & 3.9050 \\
\hline & Incomplete high school & -2.3450 \\
\hline & Complete high school & 0.5098 \\
\hline & Incomplete Higher Education & 2.6193 \\
\hline & Complete Higher Education & Reference \\
\hline \multirow{6}{*}{ Age } & Less than 30 years & Reference \\
\hline & Between 30 and 40 years & 4.6146 \\
\hline & Between 40 and 50 years & 4.7595 \\
\hline & Between 50 and 60 years & 2.7042 \\
\hline & Between 60 and 70 years & 2.9472 \\
\hline & Over 70 years & 1.7052 \\
\hline \multirow{5}{*}{ Region } & North & -162.1816 \\
\hline & Northeast & -171.1055 \\
\hline & Southeast & Reference \\
\hline & South & -36.4302 \\
\hline & Midwest & -34.1590 \\
\hline \multirow{6}{*}{ Population } & Up to 5,000 inhabitants & 232.8852 \\
\hline & Between 5,000 and 10,000 inhabitants & 122.1706 \\
\hline & Between 10,000 and 20,000 inhabitants & 74.3522 \\
\hline & Between 20,000 and 50,000 inhabitants & 37.8609 \\
\hline & Between 50,000 and 100,000 inhabitants & 15.7269 \\
\hline & Over 100,000 inhabitants & Referência \\
\hline ICSAP & - & -0.1659 \\
\hline \multirow{2}{*}{ Hospital production per thousand inhabitants } & Medium Complexity & 0.7679 \\
\hline & High Complexity & 12.8200 \\
\hline \multirow{7}{*}{ Municipal expenditures } & Primary Healthcare & 0.1035 \\
\hline & Hospital Care & 0.1540 \\
\hline & Health Surveillance & 0.2047 \\
\hline & Employment & 0.0537 \\
\hline & Primary School & -0.0482 \\
\hline & Sanitation & 0.0442 \\
\hline & Sport and Leisure & 0.0397 \\
\hline \multirow{5}{*}{ Ideological spectrum } & Left & 2.4078 \\
\hline & Center-Left & 4.4163 \\
\hline & Center-Right & Reference \\
\hline & Right & 7.6606 \\
\hline & Others & -1.8868 \\
\hline \multirow{4}{*}{ Ideological spectrum ${ }^{*}$ Year (interactive term) } & Left $*$ Year & -0.7723 \\
\hline & Center-Left * Year & -1.0150 \\
\hline & Center-Right $*$ Year & Reference \\
\hline & Right $*$ Year & -0.0959 \\
\hline
\end{tabular}

Source: Siops, SIHSUS-Datasus, Munic-IBGE and Finbra-Siconfi. 
The results also reinforce the second hypothesis, namely a positive impact of municipalities being inserted in the most developed regions on per expenditure capita. With the Southeast region as a reference, the relationship was negative for all other regions; in order of distancing starting from the Midwest, South, North until reaching the Northeast. It is also an expected result, considering the historical regional inequalities in the distribution of tax revenue in Brazil and the limited effect of the FPM on its compensation (Marenco et al., 2017; Baião et al., 2017), something of concern considering the already mentioned fact in this work that their own revenues constitute practically $60 \%$ of the municipal resources for the healthcare sector.

The third hypothesis, namely a positive impact of technological incorporation on per capita expenditure, the results considering the data referring to hospital production were not the same for medium and high complexity hospitalizations. Although a positive correlation is noticed between municipal per capita expenditure using their own revenues and medium complexity hospitalizations, the same correlation is much more robust in the case of high complexity hospitalizations, which essentially suggests a greater pressure on those expenses in the case of those municipalities which exercise the function of regional pole.

On the other hand, the fourth hypothesis, namely the negative impact of the effort spent on basic care on per capita expenditure, was not supported by the research. Although a positive correlation was found for the per capita allocation in primary healthcare, it was shown to be weak, even when compared to other budgetary sub-functions in healthcare. However, when the effort in primary healthcare was measured through the Icsap analysis (the lower this index, the greater the presumed effort of the municipality in primary healthcare), a negative correlation (albeit weak) with the expenditure per capita was found. It makes sense that greater resolution in primary healthcare explains the lower number of hospitalizations and lesser pressure to carry out procedures of medium and high complexity, and thus less municipal expenditure on healthcare, fatally spilling over on those performed with their own revenues.
The fifth hypothesis, namely a positive impact of municipal governments' exposure to left-wing parties on per capita spending, was not supported by the data either. On the contrary, a much more robust positive association was seen between a municipality'sper capita expenditure using own revenues on healthcare and the affiliation of mayors to right-wing parties than with left and center-left parties, with a negative correlation for mayors of parties which were not classified in the political ideological spectrum. The more robust positive association for right-wing parties needs further exploration, and it is plausible that this result stems more from the predominance of parties from the center to the right in smaller municipalities and with the passage of time and migration of party preferences in more developed regions, which can be seen in Figure 4. The interaction between the year and ideological spectrum variables indicates that despite the aforementioned difference, the effect tends to be mitigated, since all the interaction coefficients were negative.

It is true that the studies already mentioned herein (Rodrigues, 2007; Ribeiro, 2013) drew attention to the low or null impact of the ideological political orientation on investment in social policies, which could be attributed in large part to the conditions of Brazilian federalism, with vertical and horizontal controls designed to constrain divestment options in social policies. In turn, Guerra et al. (2018) point out that the expansion of public spending in Brazil is more likely due to the electoral calendar than due to the ideological-party bias, which may be more impactful on certain policies than others, such as increasing expenses on more tangible and observable works by voters than with education. However, the results found herein suggest that the migration of positions in the city halls between the parties, considering the population size and insertion region, may configure variations which are not exactly explained by the ideological political choices, since in Brazilian federalism the mayors face constraints to their respective mandates to both expand and significantly constrain healthcare expenditures.

Finally, regarding the sixth hypothesis, namely a negative association between higher levels of per capita expenditure on healthcare and lower allocation levels 
Figure 4 - Distribution of Parties According to Ideological Orientation, Brazil, 2005-2017.
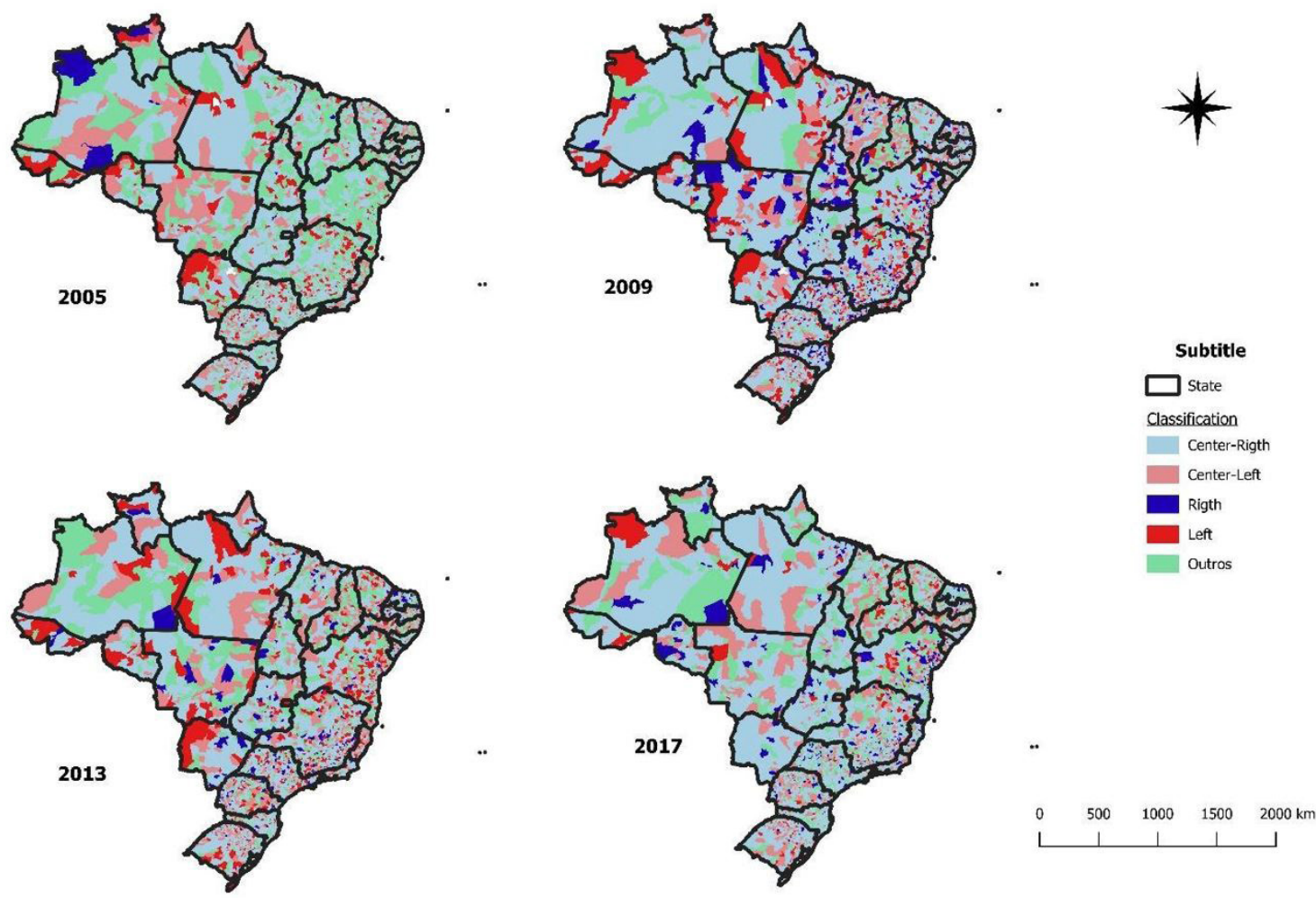

Source: Munic, 2005, 2009, 2013, 2017.

to other budgetary functions of interest to health, the results were inconclusive. On the one hand, in measuring expenditure on these other functions as per capita figures there was a positive correlation for expenditure on employment, sanitation and sports and leisure, whereas this correlation was negative for expenditure on primary education. However, the negative correlation, even if weak, between healthcare expenditure and primary education in the municipalities was contrary to expectations, since it is also a sub-function subject to strong federal regulation, and deserves special attention.

Brazilian municipalities have played a fundamental role in public educational policy (Loyola, 2017), being a fundamental link in producing changes in access to basic education and in increasing public spending in this sector (Loyola, 2017) under the influence of the Fundef and Fundeb policies. Universal coverage was promoted in primary education and a progressive expansion and diversification of the offer between different levels of education (daycare centers, pre- school, primary education, high school) under the latter two, and unlike in health policy, municipalities are required to allocate $25 \%$ of their own revenues.

However, more recent studies have addressed the fact that populations of compulsory school age are in decline, reducing the demand for enrollment in preschool and elementary schools (Saraiva, 2020). In addition, Ferreira (2020) found something for the Minas Gerais municipalities that maybe it is plausible for the country as a whole and which deserves to be better explained: the budgetary effort in education in this state fell from $23.69 \%$ (therefore, already below the $25 \%$ recommended by the Federal Constitution) to $23.17 \%$ between 2005 and 2015 . We have no elements to affirm that both phenomena are related, namely a reduction of aggregate demand in basic education and reduction of budgetary effort in education, but the data obtained in this work are suggestive that budgetary ties at the local level and the reduced budgetary flexibility of public managers is not 
immune to their strategic choices within the limits of surveillance and punishment by control bodies.

The fact is that the perception of an association between the overallocation of using their own expenditures on healthcare and an underallocation of their funds in education, both in terms of per capita and in proportion to the budget, leads to the supposition that mayors end up making compensatory choices considering the demanding pressure for services. And it is also plausible to suppose that, in doing so, they are compensating the overallocation to healthcare with a sub-allocation in education, which could allow them to have resources to carry out other functions whose allocation is not constitutionally linked, such as in the functions of employment, sanitation and sports and leisure. Added to the aforementioned that in the context of underfunding the healthcare system and its specific characteristics, political choices in the municipalities may be due to prioritizing the cost and investment of tangible actions in the short and medium term (where healthcare could be included) at the expense of long-term actions (as in educational policy). In any event, this question requires further studies.

\section{Final Considerations}

This work sought to find the reasons for Brazilian municipalities overallocating their own revenues to spend on healthcare, a phenomenon which has progressively developed since the promulgation of Constitutional Amendment 29/2000, contrary to what happened with the Federal and State governments, which adjusted to the minimum constitutional requirements. We started from the premise that there are two factors to explain the great variations between the proportions of the municipalities own revenues being allocated to healthcare which can, in the end, contribute to explain the allocation which is much higher than the required floor, and so two questions were delimited: (1) what factors explain the overallocation of expenditure using their own revenues on healthcare by Brazilian municipalities, considering the constitutionally required levels? (2) has the overallocation of these healthcare expenditures been accompanied by restrictions on spending levels in other government areas which are also of interest in guaranteeing the right to health?

In a more general sense, the descriptive analysis of the data showed the municipalities' growth of the average and median per capita expenditure using their own revenues on healthcare over the analyzed period, although with different intensities. It was emphasized that inequalities increase over time, given that the growth of the average per capita expenses using their own revenues among the municipalities which allocate more expenses (3rd quartile) was clearly higher than the growth presented by those which allocate less (1st quartile). Next, using a panel analysis model for mixed effects covering the period 2008-2017, it was possible to advance in clarifying the effects of the examined variables. Thus, it was preliminarily found that the individual attributes of local managers did not show any relationship with the per capita expenditure degree with their own health revenues. However, we find compelling results for the hypotheses explored in this work.

Some factors were certainly less useful to understand the study problem. The positive association between per capita expenditure using their own revenues and economic and social development, although it is a fundamental element to understand the variations of this type of expenditure between municipalities, does little to explain the overallocation in general. As a matter of fact, the restrictions found in the North and Northeast regions end up acting as a brake on the national average allocation of per capita expenses, which would tend to be even greater if municipalities in these regions allocated the same levels as in other regions.

Similarly, the distribution of mayors' party preferences does little to explain the dependent variable. There was no significant association between the dependent variable and the time of exposure to left-wing parties, while the association with longer exposure time to right-wing parties may be related to their majority presence in smaller cities in the South and Southeast; a factor which deserves clarification in future investigations. However, not only is there little support in the literature for any mechanism which produces this association, but also for the purposes of this work it was concluded that it did 
not point to something which helps to explain the overallocation.

In another way, the negative association between the population size of the municipality and its per capita expenditure using its own revenues on healthcare points to something much more significant. The finding suggests losses in economies of scale in the production of services in smaller municipalities, with an aggravating difficulty of attracting medical workforce to those places which are more distant from large urban centers if not using high levels of remuneration. Since the municipalities are the main implementers of public healthcare policy, and considering the fact that practically $70 \%$ of these have up to 20 thousand inhabitants, it is plausible that losses in economies of scale will help explain the overallocation of resources. Unlike for the state governments, the distribution of responsibilities in SUS directly involves municipalities in the production of services, which makes them more vulnerable to eventual inefficiencies, with overallocation being a symptom of the latter.

Another plausible explanation for the overallocation of expenditure using their own revenues by the municipalities (in this case of medium and large size) is based on the positive association between per capita expenditure and the level of technological complexity incorporated into the services; moreover, it is possible that pole municipalities (or of regional reference) allocate an additional amount of their own revenues because they are not adequately compensated by SUS transfers for medium and high complexity, which should cover the needs of the entire healthcare region. However, as we could see, the correlations were positive for hospitalizations of high complexity, but not of medium complexity. This suggests the need to deepen the operation of the supposed causal mechanism, meaning that high technological complexity resources more strongly respond to the effect of putting pressure on municipality expenditure using their own revenues on healthcare than those of medium complexity.

The relationship between per capita expenditure using its own revenues and the municipality's effort in primary healthcare was different, depending on the variable selected for the analysis. Whether the effort was represented by the per capita expenditure on primary healthcare or by the percentage of primary healthcare in total healthcare expenditure, they have a positive effect (although weak in the first case) so that the greater the effort for primary healthcare, the greater the expenditure per capita using their own revenues. In another direction, if the effort is represented by a reduction in the ICSAP or hospitalizations sensitive to primary healthcare, the negative effect for per capita expenditure is presented, so that the greater the effort with primary healthcare (controlling diseases and avoiding unnecessary hospitalizations), the lower this last type of expenditure. Although this is an unfinished point of the study, two explanations are possible. On the one hand, larger expenditures in primary attention are associated to smaller municipalities (Cabreira et al. 2018), those which have the highest per capita expenditure using their own revenues. On the other hand, decrease in the ICSAP requires more expenses with own revenues, since it depends on investing in other levels of complexity than just primary care.

In response to the second question, it is concluded that even though municipalities' high allocation levels of their own revenues on healthcare may constrain the allocation to other functions of health interest, this phenomenon is not widespread and they can also be positively associated with other functions of health interest. At this point, one of the study's greatest contributions was to show that municipalities' higher levels of per capita expenditure using their own revenues on healthcare were associated with lower levels of expenditure on basic education. However, this finding requires its own research agenda in which municipal political choices are better understood.

Brazil is one among dozens of countries who establish expenditure earmarking on public healthcare (Cashin et al., 2017), however offering an interesting example about how it works in the case of national systems with decentralized management to the local governments. The exploration of the hypotheses at this study suggested two variables which may be contributing to the overallocation of municipalities spending their own revenues on healthcare, namely the population scale in an inverse relationship, and a concentration of greater technological complexity 
services in a direct relationship. In the first case, losses in economies of scale would result from decentralizing the implementation of SUS which favors the municipalities, among which small municipalities are largely predominant. In the latter, the insufficiency of federal resources in the cost of medium and high complexity services may be putting pressure on medium and large municipalities, especially those which are a pole or regional references, to disburse more of their own healthcare revenues to cover expenses. Although in the Brazilian case, healthcare expenditure earmarking extends to the three levels of government, but the two variables specifically pressure the public spending in the level of government directly responsible for the provision of services: the municipalities.

\section{ACKNOWLEDGMENTS}

To Fundação de Amparo à Pesquisa do Estado de Minas Gerais - FAPEMIG for funding the research Estudo dos Determinantes e Impactos do Gasto Municipal em Saúde", held in the period 2017-2019, from which this article originated.

\section{Notas}

1 Tradução: Christopher J. Quinn.

2 For data referring to the mayor's party, the classification proposed by Almeida (2015) was adopted.

3 The "microdatasus" package, created by Saldanha, Bastos and Barcellos (2019), was used for data extraction. This option limited the analysis in this work to the years after 2008

4 Expense amounts were deflated using the Getúlio Vargas Foundation's General Price Index (IGP/FGV) to enable comparison of the amounts between 2008 and 2017.

\section{REFERENCES}

ABRUCIO, Fernando Luís. (2005), “A Coordenação Federativa no Brasil: a experiência do Período FHC e os desafios do Governo Lula”. Revista de Sociologia e Política, 24: 31-67.
AFONSO, José Roberto. (2006), Novos desafios à descentralização fiscal no Brasil: as políticas sociais e as de transferências de renda. Paper presented at the XVIII Seminar on Fiscal Policy, Santiago, Chile, January 26. Available in https://www.cepal. org/ilpes/noticias/paginas/5/22145/26jan07jrafonso-brasil.pdf, consulted on 3/2/2020

ALFRADIQUE, Maria Emilia; BONOLO, Palmira de Fátima; DOURADO, Inês; LIMA-COSTA, Maria Fernanda; MACINKO, James; MENDONÇA, Claunara Schilling; OLIVEIRA, Veneza Berenice; SAMPAIO, Luís Fernando Rolim; DE SIMONI, Carmen; TURCI Maria Aparecida. (2009), "Internaçóes por condições sensíveis à atenção primária: a construção da lista brasileira como ferramenta para medir o desempenho do sistema de saúde (Projeto ICSAP Brasil)". Cadernos de Saúde Pública, 25, 6: 1337-1349.

ALLERS, Maarten Adriann \& DE GREEF, J. A. (2018), "Intermunicipal cooperation, public spending and service levels". Local Government Studies, 44, 1: 127-150.

ALMEIDA, Maria Hermínia Tavares de. (2005), "Recentralizando a federação?". Revista de Sociologia e Politica, 24: 29-40.

ALMEIDA, Maria Hermínia Tavares de. (2007), "O Estado no Brasil Contemporâneo: um passeio pela história”, in C. R. Melo \& M. A. Sáez (org.), A Democracia Brasileira: balanço e perspectivas para o século 21, Belo Horizonte, Editora UFMG.

ARAÚJO, Carmem Emmanuely Leitão; GONÇALVES, Guilherme Quaresma \& MACHADO, José Angelo. (2017), "Os municípios brasileiros e os gastos próprios com saúde: algumas associaçōes", Ciência \& Saúde Coletiva, 22: 953-963.

ARRETCHE, Marta. (2012), Democracia, federalismo e centralização no Brasil. Rio de Janeiro, FGVFIOCRUZ.

BAIÂO, Alexandre Lima; CUNHA, Armando Santos Moreira \& SOUZA, Flávio Sério Rezende Nunes (2017), "Papel das transferências intergovernamentais na equalização fiscal dos municípios brasileiros". Revista do Serviço Público, 68, 3: 583-610.

BRASIL. (1988), "Constituição da República Federativa do Brasil”. Brasília, Supremo Tribunal Federal. Disponível em < https://www.bmn.com. 
$\mathrm{br} / \mathrm{plan}-\mathrm{leg} / \mathrm{ma} / \mathrm{fed} / \mathrm{cf} / \mathrm{cf}-88 . \mathrm{pdf}>$, consultado em 28/10/2019.

BRASIL. (2017), "Ministério da Saúde - Gabinete do Ministro - Portaria 2.436, de 21 de setembro de 2017”. Brasília, Ministério da Saúde. Disponível em < https://bvsms.saude.gov.br/bvs/saudelegis/ gm/2017/prt2436_22_09_2017.html>, consultado em 28/10/2019.

CABREIRA, Fabiana da Silva; RITTER, Fernando; AGUIAR, Violeta Rodrigues \& CELESTE, Roger Keller. (2018), "Despesas municipais em atenção primária à saúde no Rio Grande do Sul, Brasil: um estudo ecológico", Cadernos de Saúde Pública, 34(12).

CASHIN, Cheryl; SPARKES, Suzan; \& BLOOM, Danielle. (2017), "Earmarking for health: from theory to practice". Geneva, World Health Organization. Disponível em < https://apps.who.int/iris/bitstream/ handle/10665/255004/9789241512206-eng. pdf >, consultado em 30/10/2020.

De MELLO, Luís. (2003), Fiscal decentralization and subnational expenditure policy. International Monetary Fund (mimeo). Disponível em $<$ https://www.researchgate.net/profile/ Luiz_De_Mello/publication/267548213_ FISCAL_DECENTRALIZATION_AND_ SUBNATIONAL_EXPENDITURE_POLICY/ links/5465cc740cf2f5eb17ff68cd.pdf>, consultado em 30/10/2020.

Di PORTO, Edoardo; PARENTI, Angela; PATY, Sonia \& ABIDI, Zineb. (2017), "Local government cooperation at work: a control function approach". Journal of Economic Geography, 17: 435-463.

ELAZAR, Daniel Judah. (1987), Exploring federalism. Tuscaloosa, The University of Alabama Press.

FALLETI, Tulia Gabriela. (2005), "A sequential theory of decentralization: Latin American cases in comparative perspective". American Political Science Review, 99, 3: 327-346.

FAUSTO, Márcia Cristina Rodrigues; RIZZOTO, Maria Lucia Frizon; GIOVANELLA, Ligia; SEIDL, Helena; BOUSQUAT, Aylene; ALMEIDA, Patty Fidelis de; \& TOMASI, Elaine. (2018), "O futuro da Atenção Primária à Saúde no Brasil”. Saúde em Debate, 42: 12-14.
FERREIRA, Vítor Barcelos. (2020), Dilemas Federativos e Construção de Capacidades em Nivel Local: uma análise dos fatores associados ao FUNDEB na educação infantil. Dissertação de Mestrado. Fundação Joāo Pinheiro, Belo Horizonte.

GREER, Scott L. (2010), "How Does Decentralisation Affect the Welfare State? Territorial Politics and the Welfare State in the UK and US". Journal of Social Policy, 39, 2: 181-201.

GUERRA, Daniel; PAIXAO, Adriano Nascimento da; LEITE FILHO, Paulo Amilton Maia. (2018), "Os Ciclos Político-Econômicos e os Gastos dos Estados no Brasil: 1995-2013”. Dados, 61, 3: 695-734.

IBGE. (2018), "Perfil dos municípios brasileiros: 2017". Rio de Janeiro, IBGE. Disponível em <https:// agenciadenoticias.ibge.gov.br/media/com_mediaibge/ arquivos/496bb4fbf305cca806aaa167aa4f6dc8. pdf>, acesso em 15/12/2019.

IFI - Instituição Fiscal Independente. (2018), "RAF - Relatório de Acompanhamento Fiscal". Brasília, Senado Federal. Disponível em http:// www12.senado.leg.br/ifi/publicacoes-ifi., acesso em 17/2/2020.

IUNES, Roberto Fontes. (1995), "Concepção econômica de custos", in S. F. Piola \& S. M. Vianna (organizadores), Economia da saúde: conceitos e contribuiçôes para a gestão da saúde, Brasília, Instituto de Pesquisa Econômica Aplicada.

LAZZARI, João Batista. (2003), "Fontes de Financiamento do Sistema Único de Saúde". Revista de Direito Sanitário, 4, 1: 75-84.

LOYOLA, Paulo. (2017), "Autonomia Municipal e Interdependência Federativa: uma análise sobre as mudanças ocorridas no acesso e nos gastos em educaçáo no Brasil (2000 - 2014)". Educação e Sociedade, 38, 140: 767-790.

MACHADO, José Angelo \& GUIM, Ana Luíza dos Santos. (2017), "Descentralização e igualdade no acesso aos serviços de saúde: o caso do Brasil". Revista do Serviço Público - RSP, 68, 1:37-64.

MACHADO, José Angelo; QUARESMA, Guilherme \& ARAUJO, Carmem E. Leitão. (2020), "Municipal expenditures using own-source revenues and resilience of territorial inequalities in health". Saúde e Sociedade, 29, 4: 1-15. 
MARENCO, André. STROHSCHOEN, Maria Tereza Blanco \& JONER, William. (2017), "Capacidade estatal, burocracia e tributação nos municípios brasileiros”. Revista de Sociologia e Política, 25, 64: 3-21.

MASSUDA, Adriano. (2020). Mudanças no financiamento da Atenção Primária à Saúde no Sistema de Saúde Brasileiro: avanço ou retrocesso?. Ciência \& Saúde Coletiva, 25, 1181-1188.

MATTOS, Enlinson; ROCHA, Fabiana; NOVAES, Lucas; ARVATE, Paulo \& ORELLANO, Verônica. (2010), Economias de escala na oferta de serviços públicos de saúde: um estudo para os municípios paulistas - Textos para discussão 269. São Paulo, FGV.

MEIRELES, Fernando. (2018). DeflateBR: Deflate Nominal Brazilian Reais. R package version 1.1.2, 2018. Disponível em: https://CRAN.R-project. org/package $=$ deflateBR, acesso em 11/11/2019.

MENDES, Eugênio Vilaça. (2001), Os Grandes Dilemas do SUS: tomo II. Salvador, Casa da Qualidade Editora.

MENICUCCI, Telma Maria Gonçalves. (2009), O Sistema Único de Saúde, 20 anos: balanço e perspectivas. Cadernos de Saúde Pública, 25, 7:1620-1625.

NIAOUNAKIS, Thomas \& BLANK, Jos. (2017), "Inter-municipal cooperation, economies of scale and cost efficiency: an application of stochastic frontier analysis to Dutch municipal tax departments". Local Government Studies, 43, 4: 533-554.

OATES, Wallace E. (1999), "An Essay on Fiscal Federalism". Journal of Economic Literature, 37, 3: 1120-1149.

OBINGER, Herbert; LEIBFRIED, Stephan \& CASTLES, Francis. (2005), Federalism and the Welfare State: New World and European Experiences. New York, Cambridge University.

OLIVEIRA, Fabrício Augusto. (2010), A evolução da estrutura tributária e do fisco brasileiro: 18892009 - No. 1469. Brasília, IPEA.

PASCHOALOTTO, Marco Antônio; PASSADOR, João Luiz; OLIVEIRA, Lílian Ribeiro; LOPES, José Eduardo; DANTAS, Marina Kolland
\& PASSADOR, Cláudia Souza. (2018), “A regionalização do SUS: Proposta de avaliação do desempenho dos Departamentos Regionais de Saúde do estado de São Paulo". Saúde \& Sociedade, 27, 1: 80-93.

PINTO, Luís Felipe; MENDONÇA, Claunara Shilling; REHEM, Tânia Cristina Morais Santa Bárbara. \& STELET, Bruno. (2019), "Internaçôes por Condições Sensíveis à Atenção Primária (ICSAP) no Distrito Federal: comparação com outras capitais brasileiras no período de 2009 a 2018”. Ciência \& Saúde Coletiva, 24, 6: 2105-2114.

PIOLA, Sérgio Francisco. (2017), Transferências de Recursos Federais do Sistema Único de Saúde para Estados, Distrito Federal e Municipios: os desafios para a implementação dos critérios da Lei Complementar No 141/2012. Brasília, IPEA.

PIOLA, Sérgio Francisco; FRANCA, José Rivaldo Mello \& NUNES, André. (2016), "Os efeitos da Emenda Constitucional 29 na alocação regional dos gastos públicos no Sistema Único de Saúde no Brasil". Ciência e Saúde Coletiva, 21, 2: 411-422.

PÓVOA, Luciano \& ANDRADE, Mônica Viegas. (2006), "Distribuiçâao geográfica dos médicos no Brasil: uma análise a partir de um modelo de escolha locacional”. Cadernos de Saúde Pública, 22: $1555-1564$.

REZENDE, Fernando. (2010), "Federalismo fiscal: em busca de um novo modelo", in OLIVEIRA, Romualdo Portela \& SANTANA, Wagner (org.), Educação e federalismo no Brasil: combater as desigualdades, garantir a diversidade. Brasilia, UNESCO, 71-88.

RIBEIRO, Leandro Molhano (2013), "Federalismo, Governo Local e Políticas Sociais no Brasil entre 1996 e 2004 ", in G. Hochman \& C. A. P. Faria, Federalismo e Políticas Públicas no Brasil, Rio de Janeiro, Editora FIOCRUZ.

RODRIGUES, Gilmar. (2007), "Democracia e Partidos Políticos: os gastos públicos municipais como instrumento de análise político-ideológica", in G. Hochman; M. Arretche \& E. Marques (Orgs), Politicas Públicas no Brasil, Rio de Janeiro, FIOCRUZ. 
SALDANHA, Raphael de Freitas; BASTOS, Ronaldo Rocha \& BARCELLOS, Christovam. (2019), "Microdatasus: pacote para download e préprocessamento de microdados do Departamento de Informática do SUS (Datasus)". Cadernos de Saúde Pública, 35, 9, e00032419. Disponível em < https:/www.scielosp.org/pdf/csp/2019.v35n9/ e00032419/pt>, acesso em 3/2/2020.

SARAIVA, Agnez de Lélis. (2020), Capacidade municipal de implementação de politicas educacionais: o sistema federativo de Educação Básica e os municípios. Tese de Doutorado. UFMG-FAE, Belo Horizonte.

SCATENA, João Henrique Gurtler; VIANA, Ana Luiza d'Ávila \& TANAKA, Oswaldo Yoshimi. (2009), "Sustentabilidade financeira e econômica do gasto público em saúde no nível municipal: reflexões a partir de dados de municípios mato-grossenses". Cadernos de Saúde Pública, 25: 2433-2445.

SILVA, Ivanise Brito. (2017), "Desafios do Financiamento da Atenção Primária à Saúde: revisão integrativa”. Revista Brasileira de Promoção da Saúde, 30, 1 : 110-117.

SILVA, Maurício Corrêa; MACIEL, João Halberto Balduino; CHACON, Márcia Josienne Monteiro \& ARAÚJO, Aneide Oliveira. (2012), "Gastos com saúde: uma análise do cumprimento da Emenda Constitucional no 29/2000 pelos 100 municípios brasileiros mais populosos, no período de 2000 a 2008”. REUNIR - Revista de Administração, Contabilidade e Sustentabilidade, 2, 1:1-20.

SILVA, Mauro Santos. (2005), "Teoria do federalismo fiscal: notas sobre as contribuiçôes de Oates, Musgrave, Shah e Ter-Minassian”. Nova Economia, 15, 1: 117-137.
SIOPS, Indicadores Municipais, 2019. Disponível em $<$ http://siops-asp.datasus.gov.br/CGI/deftohtm. exe?SIOPS/serhist/municipio/mIndicadores.def>, acesso em 12/12/2019

STARFIELD, Barbara. (2002), Atenção primária: equilibrio entre necessidades de saúde, serviços e tecnologia. Brasília, UNESCO - Ministério da Saúde.

STRALEN, Ana Cristina Sousa Van; MASSOTE, Alice Werneck; CARVALHO, Cristiana Leite \& GIRARDI, Sabado Nicolau. (2017), "Percepção de médicos sobre fatores de atração e fixação em áreas remotas e desassistidas: rotas da escassez". Physis, 27, 1: 147-172.

VAZQUEZ, Daniel Arias. (2011), "Efeitos da regulação federal sobre o financiamento da saúde". Cadernos de Saúde Pública, 27, 6: 1201-1212.

VIANNA, Sólon Magalhães; NUNES, André; GOES, Geraldo; SILVA, Joelmir R.; SANTOS, René José Moreira dos; DANTAS JR, Edson Albano; PEREIRA, Handerson Gonçalves; LIMA, Luís Renato Costa \& VALDES, Raucélio Coelho C. (2005), "Atenção de alta complexidade no SUS: desigualdades no acesso e no financiamento", in A. M. L. Perocco; A. M. N. Raggio \& S. V. Magalhães, Projeto Economia da Saúde - PES: reforçando sistemas de saúde para reduzir desigualdades (2002-2005). Brasília, Ministério da Saúde/ Instituto de Pesquisa Econômica Aplicada.

VIEIRA, Fabiola Sulpino \&BENEVIDES, Rodrigo Pucci de Sá. (2016), Os impactos do novo regime fiscal para o financiamento do Sistema Único de Saúde e para a efetivação do direito à saúde no Brasil. Brasília, IPEA. 


\section{MUCH BEYOND THE \\ MINIMUM: WHY DO \\ BRAZILIAN MUNICIPALITIES \\ OVERALLOCATE THEIR OWN \\ REVENUES TO HEALTHCARE?}

José Angelo Machado, Guilherme

Quaresma, Carmem E. Leitáo Araújo

Keywords: Fiscal federalism, Constitutional Amendment 29/2000, health expenditure, own revenues, municipalities.

This article identifies reasons for Brazilian municipalities overallocating their own revenues to healthcare which, since the promulgation of Constitutional Amendment 29/2000, have progressively expanded them until they far exceed the constitutional minimum. Linear regression models with mixed panel effects were used for the period of 2008-2017. The tested hypotheses are related to the effects of the population scale of the municipalities; the level of economic and social development of the region in which they operate; the degree of incorporation of technological resources of medium and high complexity; the effort spent on basic care; political guidance from municipal governments; and, finally, to allocation to other budgetary functions and sub-functions of interest to healthcare. The results point to two factors which better explain the dependent variable: the population scale in inverse relation, and the concentration of greater technologically complex services in a direct relation.

\section{MUITO ALÉM DO MÍNIMO: POR QUE OS MUNICÍPIOS BRASILEIROS ALOCAM SUAS PRÓPRIAS RECEITAS PARA A SAÚDE?}

José Angelo Machado, Guilherme Quaresma, Carmem E. Leitão Araújo

Palavras-chave: Federalismo fiscal, Emenda Constitucional 29/2000, despesa com saúde, receitas próprias, municípios.

$\mathrm{O}$ artigo identifica razōes para a superalocação de receitas próprias com saúde pelos municípios brasileiros que, desde a promulgação da EC 29/2000, as ampliaram progressivamente até ultrapassar em muito o piso constitucional. Modelos de regressão linear com efeitos mistos em painel foram utilizados para o período 2008-2017. As hipóteses testadas estáo relacionadas aos efeitos da escala populacional dos municípios; nível de desenvolvimento econômico e social da região em que se inserem; grau de incorporação de recursos tecnológicos de média e alta complexidade; esforço despendido com atenção básica; orientação político partidária dos governos municipais; além da alocação em outras funçôes e sub funções orçamentárias de interesse da saúde. Os resultados apontam para dois fatores que melhor explicam a variável dependente: escala populacional, em relação inversa, e concentração de serviços de maior complexidade tecnológica, em relação direta.

\section{BEAUCOUP AU-DELÀ DU MINIMUM: POURQUOI LES MUNICIPALITÉS BRÉSILIENNES SURUTILISENT-ELLES LEURS PROPRES REVENUS POUR LA SANTÉ?}

José Angelo Machado, Guilherme Quaresma, Carmem E. Leitão Araújo

Mots-clés: Fédéralisme fiscal, amendement constitutionnel 29/2000, dépenses de santé, revenus propres, municipalités.

Cet article identifie les raisons pour lesquelles les municipalités brésiliennes surallouent leurs propres revenus aux soins de santé qui, depuis la promulgation de l'amendement constitutionnel 29/2000, les ont progressivement étendus jusquà dépasser largement le minimum constitutionnel. Des modèles de régression linéaire à effets mixtes ont été utilisés pour la période 2008-2017. Les hypothèses testées sont liées aux effets de l'échelle populationnelle des municipalités; au niveau de développement économique et social de la région dans laquelle elles opèrent; au degré d'incorporation des ressources technologiques de complexité moyenne et élevée; à l'effort consacré aux soins de base; à l'orientation politique des gouvernements municipaux; et, enfin, à d'autres fonctions et sous-fonctions budgétaires concernant les soins de santé. Les résultats mettent en évidence deux facteurs qui mieux expliquent la variable dépendante: l'échelle populationnelle en relation inverse et la concentration de services plus complexes technologiquement en relation directe. 